\title{
IMPREGNATION OF HANDKERCHIEFS, ULTRA-VIOLET LIGHTING, AND OTHER CONTROL METHODS IN PREVENTION OF UPPER RESPIRATORY DISEASE
}

\author{
BY \\ T. C. MACDONALD, A.F.C., Air Cdre., R.A.F., \\ J. D. TONKINSON, Wg. Cdr., R.A.F., J. PORTERFIELD, Sqn. Ldr., R.A.F., \\ AND K. R. DUMBELL, Sqn. Ldr., R.A.F. \\ From the Directorate of Hygiene and Research, Air Ministry
}

A large training station of the Royal Air Force, situated in Southern England, offered unusually good facilities for controlled trials of possible methods of reducing the spread and incidence of upper respiratory infections.

\section{MATERIAL}

The total population of some 4,000 persons included at the relevant times between 1,200 and 1,800 young apprentices organized in three "Wings". Each of these wings had its own similar barrack and dining rooms (in permanent brick buildings), its own Service Institutes for use in leisure hours, and its own specially allotted sections of the large and airy workshops. Intermingling of the wings was, therefore, largely limited to open-air activities, with, to a smaller extent, some mixing off-duty and in a communal station cinema. The wings were themselves sub-divided into three "Squadrons", and these too, were fairly self-contained and separate units, though not so decisively separated as the wings. In general, this structure, coupled with a highly organized medical service and method of sickness recording, made it administratively possible, and indeed simple, to set up "experimental" groups to be compared with "control" groups, both groups being very similar in their characteristics and conditions of life, but living and working largely apart.

The apprentices enter the service, usually direct from school, between the ages of $15 \frac{1}{2}$ and 17 in thrice-yearly entries; and they remain on the station for 3 years. Their health is good and their height and weight gains during the 3 years equal to, or better than, the average of youths in other occupations (Morant, 1949). The station was organized as a school with three terms per year, each with a short mid-term break, and holidays at the usual times but rather shorter than normal.

\section{Procedure}

In this setting it was decided to make a trial of impregnated handkerchiefs as a possible means of reducing the spread of upper respiratory infections.
Methods of IMPREgNATION.-Dumbell, Lovelock, and Lowbury (1948) drew attention to the large number of airborne bacteria-carrying particles which were liberated by a handkerchief as normally used, and in a subsequent paper, Dumbell and Lovelock (1949) reported that handkerchiefs could be impregnated with various substances which would sterilize the nasal secretion deposited therein. The problem in the present trial was to find a practical method of impregnating handkerchiefs on a relatively large scale.

Solutions of hexyl resorcinol and of octyl cresol, emulsions of these substances, and direct application by a roller machine (not unlike a domestic mangle) were all tried and discarded: a reasonable consistency of impregnation allied to ease of application was eventually achieved by immersing handkerchiefs in a solution of octyl cresol in 60 per cent. alcohol. The handkerchiefs were then transferred to a very large bath of water, when most of the octyl cresol was retained in the cotton and only one-quarter to one-third was washed away with the alcohol. Impregnated in this way, handkerchiefs were found to reduce the numbers of particles carrying viable bacteria to an extent comparable with the handkerchiefs which Dumbell and Lovelock impregnated direct from alcoholic solution in their small-scale experiments. This method of impregnation was therefore adopted, although the calendering raised an unexpected difficulty in that the heated rollers caused the emission of an irritating vapour, the equivalent of a fairly effective tear gas, which almost incapacitated the operators. It was found essential for the operators to wear service anti-gas respirators-a tiresome procedure which clearly debars the use of octyl cresol on any large scale. In the present research it was in fact used in Trials I to IV.

At a later stage attention was turned to the use of glycollic acid when various new difficulties had to 


\section{T. C. MACDONALD, J. D. TONKINSON, J. PORTERFIELD, AND K. R. DUMBELL}

be overcome. The technique employed with octyl cresol and described above was unsatisfactory owing to precipitations of calcium salts from previous laundering; but a small roller machine which had been tried before was used with some success. In this machine, rollers dipping in a trough of glycollic acid transferred the latter with reasonable consistency to the handkerchiefs. On the other hand calendering was even more difficult, for when impregnated with glycollic acid the handkerchiefs stuck to the cloths of the calender, were awkward to remove from its rollers, and frequently tore its cloths. Glycollic acid was also found to cause rapid deterioration of the material of the handkerchiefs, and this ultimately brought the trial to an end (Trial V). Throughout the trials a sample of handkerchiefs was taken from each batch after calendering for a test of the impregnation-to ensure that consistent amounts were being applied and that no undue build-up of the chemical was occurring. In addition a bacteriological check was made at intervals. It was found that neither of the chemicals was as bactericidal when used on a large scale in the ways described above as in the laboratory trials with a small number of handkerchiefs. Octyl cresol was particularly disappointing.

Distinctive handkerchiefs with brightly coloured borders were obtained especially for the trials. The leading apprentice in charge of each barrack room (with a maximum of twenty occupants) was made responsible for their collection and issue; but individuals could make personal exchanges at any time in cases of necessity.

RECORDS OF ILLNESS.- - Records of attacks of upper respiratory disease came from two sources:-

(a) Attendances at the regular morning sick parade,

(b) Reports of attacks of the common cold which did not bring an apprentice to the sick parade but which he was specially instructed to report to the leading apprentice in charge of his barrack room.

Checks on these latter records were made throughout the trials by drawing at random a one per cent. sample of the population for interview. At these interviews the frequency of colds which had not been reported could be assessed. A 10 per cent. random sample of those reporting a cold was also drawn regularly to determine what was comprised by these self-diagnosed "colds".

The clinical diagnoses of upper respiratory complaints seen at the daily sick parade were divided into three groups:

(i) Cold.-The condition normally so called, characterized by sneezing, rhinorrhea and/or catarrh, lacrimation, etc., with or without pyrexia. (ii) Sore Throat.-A symptomatic diagnosis embracing tonsillitis and pharyngitis.

(iii) Influenza.-A febrile condition without localizing signs but with general symptoms such as limb pains and weakness.

(iv) Self-Diagnosed "Colds".-These were separately tabulated.

\section{RESULTS}

Trial I (March 6 to May 20, 1950). - In the first trial handkerchiefs were issued to all 1,500 apprentices in the three wings. Those issued to one particular wing were impregnated with octyl cresol; the remainder were untreated. After 4-5 weeks on this basis and following the mid-term break, all handkerchiefs were collected. On re-issue a different wing received the impregnated handkerchiefs. Such changes were, of course, unknown to the apprentices.

While there was no evidence that the impregnation was having any appreciable effect upon the occurrence of upper respiratory disease, it was found that the scale of the trial was too large for close and adequate supervision, and this trial was, therefore, abandoned.

Trial II (August 28, 1950, to April 14, 1951).Arising out of the experience of the first trial it was decided to issue handkerchiefs to one wing only. The three squadrons of this wing would form "experimental" and "control" units for comparison one with another and also to some extent, with the other wings to which no handkerchiefs had been issued. The squadrons of No. 3 wing were selected since they had between them a trade division which ensured a greater separation at work than was the case with the squadrons of the other wings.

'Handkerchiefs issued to two squadrons were impregnated with octyl cresol, those to the other squadron were untreated. Four handkerchiefs were issued weekly to each apprentice, but any apprentice using up his allocation before the end of the week could obtain a fresh supply on a one-for-one basis by a personal visit to sick quarters. Frequent checks were made by irregular inspections to ensure that the issued handkerchiefs, and not others, were being used, and several talks on the value and importance of the trials were given to the whole wing.

The results of Trial II are given in Table I. They show no differences between the group incidence of the various respiratory infections. The two squadrons given handkerchiefs impregnated with 
TABLE I

HANDKERCHIEF TRIAL II

AVERAGE WEEKLY INCIDENCE OF UPPER RESPIRATORY DISEASES FROM AUGUST 28, 1950, TO APRIL 14, 1951*

\begin{tabular}{|c|c|c|c|c|c|c|c|c|c|c|c|}
\hline \multirow[t]{2}{*}{ Unit } & \multirow{2}{*}{$\begin{array}{l}\text { Average } \\
\text { Popu- } \\
\text { lation }\end{array}$} & \multicolumn{2}{|c|}{ Colds } & \multicolumn{2}{|c|}{ Influenza } & \multicolumn{2}{|c|}{$\begin{array}{l}\text { Sore } \\
\text { Throats }\end{array}$} & \multicolumn{2}{|c|}{$\begin{array}{l}\text { Self- } \\
\text { Reported } \\
\text { Colds }\end{array}$} & \multirow{2}{*}{$\begin{array}{c}\text { Total } \\
\text { Colds } \\
\text { (Per cent.) }\end{array}$} & \multirow[t]{2}{*}{$\begin{array}{l}\text { Special Handkerchiefs } \\
\text { Issued }\end{array}$} \\
\hline & & $\%$ & No. & $\%$ & No. & $\%$ & No. & $\%$ & No. & & \\
\hline 1 Wing (Control) & 456 & $2 \cdot 2$ & 270 & 0.7 & 83 & 0.8 & 98 & $4 \cdot 7$ & 582 & 6.9 & None \\
\hline 2 Wing (Control) & 309 & $2 \cdot 6$ & 214 & 0.6 & 51 & $1 \cdot 0$ & 88 & $4 \cdot 1$ & 338 & $6 \cdot 7$ & None \\
\hline $\begin{array}{l}\text { 3.Wing } \\
\text { "A", Sqdn (Control) } \\
\text { "B", Sqdn (Trial) } \\
\text { "C" Sqdn (Trial) }\end{array}$ & $\begin{array}{l}196 \\
185 \\
210\end{array}$ & $\begin{array}{l}2 \cdot 2 \\
2 \cdot 0 \\
2 \cdot 7\end{array}$ & $\begin{array}{l}118 \\
101 \\
154\end{array}$ & $\begin{array}{l}0.5 \\
0.6 \\
1.2\end{array}$ & $\begin{array}{l}24 \\
31 \\
64\end{array}$ & $\begin{array}{l}0 \cdot 7 \\
0 \cdot 7 \\
0 \cdot 8\end{array}$ & $\begin{array}{l}36 \\
33 \\
45\end{array}$ & $\begin{array}{l}5 \cdot 2 \\
3 \cdot 3 \\
7 \cdot 1\end{array}$ & $\begin{array}{l}274 \\
165 \\
402\end{array}$ & $\begin{array}{l}7 \cdot 4 \\
5 \cdot 3 \\
9 \cdot 8\end{array}$ & $\begin{array}{l}\text { Not impregnated } \\
\text { Impregnated, Octyl cresol } \\
\text { Impregnated, Octyl cresol }\end{array}$ \\
\hline
\end{tabular}

* Excluding the Christmas holiday

octyl cresol had, taken together, an incidence rate of 2.4 per cent. for colds diagnosed at sick parade and $5 \cdot 3$ per cent. for self-reported colds. The corresponding rates for the "control" squadron were $2 \cdot 2$ per cent. and $5 \cdot 2$ per cent.

Trial III (September 1, 1951, to April 5, 1952).Despite this negative result, and pending the development of other possible methods of control, a further trial of handkerchiefs impregnated with octyl cresol was set in train. In the autumn and winter 1951-52 they were issued to one squadron while a second squadron received untreated handkerchiefs. The comparison of their experiences, and those of Wing No. 2, is given in Table II. Once again no significant distinction between the trial and control groups was found.

Trial IV (October 20, 1951, to April 5, 1952).Shortly after the start of Trial III a more comprehensive attempt was made to reduce the spread of upper respiratory infection. The aim was to close at the same time as many potential routes of spread as possible. If this "combined operation" should fail, then it would seem that further action towards the control of respiratory infections must await new knowledge of modes of spread and prevention. The potential routes taken into account and the means used to close them were as follows:

(a) Airborne infection in barrack rooms/Ultra violet irradiation of the air.

(b) Dustborne infection in barrack rooms/Oiling of floors and oil impregnation of bed-clothes and pyjamas.

(c) Direct droplet spread in barrack rooms/Screens between the beds.

(d) Infection from handkerchiefs/Impregnated handkerchiefs.

These measures were directed, it will be seen, mainly to the living accommodation. The workshops were too large and dispersed for any attempt at aerial control.

(a) Ultra-Violet Lighting.-Owing to the relatively low ceiling height specially modified lamps* were installed. The efficiency of the irradiation could not be tested by routine air sampling since the oiling of the floor and textiles might also be playing a part. A deliberate contamination of the air was therefore required. Experience indicated. that a natural and reproducible contamination could be produced by a "spraying spit"-which phrase implies the assembling of a quantity of saliva in the mouth, and its dispersal by violent blowing out through partially closed lips

* Loaned by British Thomson-Houston Ltd.

TABLE II

HANDKERCHIEF TRIAL III

AVERAGE WEEKLY INCIDENCE OF UPPER RESPIRATORY DISEASES FROM AUGUST 27, 1951, TO APRIL 5, 1952*

\begin{tabular}{|c|c|c|c|c|c|c|c|c|c|c|c|}
\hline \multirow[t]{2}{*}{ Unit } & \multirow{2}{*}{$\begin{array}{l}\text { Average } \\
\text { Popu- } \\
\text { lation }\end{array}$} & \multicolumn{2}{|c|}{ Colds } & \multicolumn{2}{|c|}{ Influenza } & \multicolumn{2}{|c|}{$\begin{array}{c}\text { Sore } \\
\text { Throats }\end{array}$} & \multicolumn{2}{|c|}{$\begin{array}{l}\text { Self- } \\
\text { Reported } \\
\text { Colds }\end{array}$} & \multirow{2}{*}{$\begin{array}{c}\text { Total } \\
\text { Colds } \\
\text { (Per cent.) }\end{array}$} & \multirow{2}{*}{ Special Handkerchiefs } \\
\hline & & $\%$ & No. & $\%$ & No. & $\%$ & No. & $\%$ & No. & & \\
\hline 2 Wing (Control) & 560 & $2 \cdot 3$ & 386 & $0 \cdot 12$ & 20 & 0.6 & 108 & $4 \cdot 2$ & 701 & $6 \cdot 5$ & None \\
\hline $\begin{array}{l}3 \text { Wing } \\
\text { "A" Sqdn (Control) } \\
\text { "B" Sqdn (Trial) }\end{array}$ & $\begin{array}{l}184 \\
142\end{array}$ & $\begin{array}{l}1.4 \\
1.6\end{array}$ & $\begin{array}{l}78 \\
70\end{array}$ & $\begin{array}{l}0.04 \\
0.09\end{array}$ & $\begin{array}{l}2 \\
4\end{array}$ & $\begin{array}{l}0.8 \\
0.6\end{array}$ & $\begin{array}{l}44 \\
27\end{array}$ & $\begin{array}{l}5 \cdot 4 \\
7 \cdot 3\end{array}$ & $\begin{array}{l}296 \\
310\end{array}$ & $\begin{array}{l}6 \cdot 8 \\
8 \cdot 9\end{array}$ & $\begin{array}{l}\text { Not impregnated } \\
\text { Impregnated, Octyl cresol }\end{array}$ \\
\hline
\end{tabular}


(Bourdillon, Lidwell, and Lovelock, 1948). The intention was to assess the efficiency of the irradiation by the rate of diminution in the bacterial count in the air, rather than by any absolute count at a given moment. Following two such spraying spits into the upper air of a barrack room, in which all the windows had been shut, air samples were taken each alternate half-minute to measure the die-away rate of the total bacterial air count produced by the spit. Tests made before the beginning of term and at the mid-term break showed a much more rapid fall in bacterial count in the irradiated rooms. It was not possible to fit dummy lamps in the rooms which were not irradiated, and as an alternative imitation "chemical disinfection" was provided. Once weekly the control barrack rooms were sprayed with a preparation of pine oil which left a "disinfectant" odour.

(b) Oiling of Textiles.-The blankets, sheets, pillowcases, and pyjamas of all the apprentices living in the test barrack blocks were oil impregnated according to the technique recommended by the Launderers' Research Association (Harwood and others, 1944) and under the supervision of a member of its staff. Blankets were impregnated in the vacation and expected to retain sufficient dust-laying power throughout the term. Sheets, pillow-cases, and pyjamas were washed and re-impregnated weekly. Special studies by Mr. T. Nash of the Central Public Health Laboratory, Colindale, showed that the desired oil content of the laundered articles was being obtained. A bacteriological test suggested by Dr. R. E. O. Williams was also employed: at intervals throughout the trial an open petri plate containing serum agar was drawn once across the blanket just below the pillow line and the total colony count made after 24 hours incubation was, on the average, less than half the count found with the unoiled blankets. The oiling of textiles was not detectable by feel or odour and therefore required no action in the control rooms.

(c) Oiling of Floors.-The floors were oiled once a week with a suitable oil issued for the purpose from the Station Stores. At the same time the control barrack blocks drew their normal floor polish from the Station
Sick Quarters as "medicated" polish instead of from the usual source.

The "medication" consisted of stirring up the smooth surface of the polish. To check the dust-laying a special dust sampler was designed by Mr. T. Nash, this consisted of a device by which jets of air, puffed through a long handle by a rubber bulb, impinged on the floor and raised a small cloud of dust, part of which was trapped on an exposed Petri dish. A considerable laying of dust was found in the test barrack rooms.

(d) Bed Screens. - Ordinary portable hospital-type folding screens were used, consisting of fabric material hung on a wooden frame. They were some $5 \mathrm{ft}$. high and effectively screened the occupants of the beds from each other.

After these measures had been brought into operation, the general bacterial content of the room air was assessed by a Bourdillon spit sampler. Tests were made approximately once a week in treated and non-treated rooms chosen at random, all tests following immediately after the apprentices had left the rooms after the luncheon break. Both sets of rooms revealed low counts, and though the treated rooms had a consistently lower level the differences were slight. These lo v counts were probably due to the good natural ve:tilation of the rooms which measured $60 \times 20 \times 10 \frac{1}{2} \mathrm{ft}$. high, with large windows down both sides and at one end.

The results of these measures are shown in Table III. The only difference of any magnitude lies in the high incidence of self-reported colds in the squadron to which the battery of preventive measures was applied. In spite of "dummy" procedures with the controls it may well be that these apprentices were made more cold-conscious and more ready to report their ailments. The sick parade figures give the following rates for colds, sore throats, and influenza combined.

TABLE III

TRIAL IV

AVERAGE WEEKLY INCIDENCE OF UPPER RESPIRATORY DISEASES FROM OCTOBER 15, 1951, TO APRIL 5, 1952*

\begin{tabular}{|c|c|c|c|c|c|c|c|c|c|c|c|}
\hline \multirow[t]{2}{*}{ Unit } & \multirow{2}{*}{$\begin{array}{l}\text { Average } \\
\text { Popu- } \\
\text { lation }\end{array}$} & \multicolumn{2}{|c|}{ Colds } & \multicolumn{2}{|c|}{ Influenza } & \multicolumn{2}{|c|}{$\begin{array}{c}\text { Sore } \\
\text { Throats }\end{array}$} & \multicolumn{2}{|c|}{$\begin{array}{c}\text { Self- } \\
\text { Reported } \\
\text { Colds }\end{array}$} & \multirow{2}{*}{$\begin{array}{c}\text { Total } \\
\text { Colds } \\
\text { (Per cent.) }\end{array}$} & \multirow[t]{2}{*}{ SpecialProcedures } \\
\hline & & $\%$ & No. & $\%$ & No. & $\%$ & No. & $\%$ & No. & & \\
\hline 2 Wing (Control) & 559 & $2 \cdot 4$ & 313 & 0.2 & 20 & $0 \cdot 8$ & 101 & $4 \cdot 5$ & 584 & $6 \cdot 9$ & None \\
\hline $\begin{array}{l}\text { 3.Wing } \\
\text { "A"Sqdn (Control) } \\
\text { “C"Sqdn (Trial) }\end{array}$ & $\begin{array}{l}188 \\
234\end{array}$ & $\begin{array}{l}1 \cdot 5 \\
2 \cdot 3\end{array}$ & $\begin{array}{r}64 \\
126\end{array}$ & $\begin{array}{l}0.05 \\
0.1\end{array}$ & $\begin{array}{l}2 \\
5\end{array}$ & $\begin{array}{l}1 \cdot 0 \\
0 \cdot 8\end{array}$ & $\begin{array}{l}43 \\
46\end{array}$ & $\begin{array}{r}5 \cdot 5 \\
10 \cdot 0\end{array}$ & $\begin{array}{l}239 \\
541\end{array}$ & $\begin{array}{r}7 \cdot 0 \\
12 \cdot 4\end{array}$ & $\begin{array}{l}\text { No general air hygiene; } \\
\text { untreated handkerchiefs } \\
\text { General air hygiene; im- } \\
\text { pregnated handkerchiefs, } \\
\text { Octyl cresol }\end{array}$ \\
\hline
\end{tabular}

* Excluding the Christmas holiday 
"C" Squadron (general air hygiene and impregnated handkerchiefs) $3 \cdot 2$ per cent.;

"B" Squadron* (impregnated handkerchiefs only) $2 \cdot 3$ per cent.;

"A" Squadron (untreated handkerchiefs only) $2 \cdot 5$ per cent.

No. 2 Wing (nothing) 3.4 per cent.

Trial V (August 24, 1952, to March 31, 1953).The final trial was of handkerchiefs impregnated with glycollic acid. Two handkerchiefs per week were issued to "C" Squadron which continued with the general air hygiene measures described above, and two untreated handkerchiefs were given to members of "A" Squadron. No. 2 Wing was also observed as a further but less efficient control group. Unfortunately the treated handkerchiefs deteriorated rapidly under the influence of glycollic acid and after 4 weeks the trial had to be abandoned. The issue of the impregnated handkerchiefs had coincided with the onset of an epidemic of influenza. The results of the trial are shown in Table IV.

This Table reveals no appreciable difference between the two squadrons in the incidence of illness diagnosed as influenza. "A" Squadron with untreated handkerchiefs had a rate of 2.4 per cent. during the "glycollic acid period" and a total rate of 2.58 per cent. between January 12 and March 28 . " $C$ " Squadron with treated handkerchiefs and general air hygiene had corresponding rates of 2.54 per cent. No. 2 Wing suffered more severely in the epidemic than either of the two squadrons in the trial (giving rates of $4 \cdot 21$ and $4 \cdot 60$ per cent.).

With sore throats there is also no convincing evidence of advantage to the squadron issued with impregnated handkerchiefs and given general air hygiene. During the "glycollic acid period" the two squadrons did not differ materially (nor statistically to a significant degree). The respective rates were 1.96 and 2.62 per cent. Subsequently the squadron with impregnated handkerchiefs had a relatively and significantly low rate of incidence, 0.55 to 1.32 per cent. It must be noted, however, that it had been in precisely the same position before the issue of impregnated handkerchiefs, when the rates were 0.35 and 1.13 per cent. Compared with No. 2 Wing the trial squadron had a similar incidence of sore throats before the issue of impregnated handkerchiefs, not significantly different during their issue, but significantly lower subsequently. This one difference is not very impressive.

* Figures from Table II which relates to almost the same period of time.
TABLE IV

AVERAGE WEEKLY INCIDENCE OF UPPER RESPIRATORY DISEASES (TRIAL V)

\begin{tabular}{|c|c|c|c|c|c|c|c|c|c|}
\hline \multirow{2}{*}{$\frac{\text { Period } \ldots}{\text { Date } \quad \cdots}$} & \multicolumn{9}{|c|}{ PRE-GLYCOLLIC ACID } \\
\hline & \multicolumn{9}{|c|}{ AUGUST 24, 1952, TO DECEMBER 6, 1952} \\
\hline \multirow[t]{2}{*}{ Unit } & \multirow{2}{*}{$\begin{array}{l}\text { Average } \\
\text { Popula- } \\
\text { tion }\end{array}$} & \multicolumn{2}{|c|}{ Colds } & \multicolumn{2}{|c|}{ Influenza } & \multicolumn{2}{|c|}{$\begin{array}{c}\text { Sore } \\
\text { Throat }\end{array}$} & \multicolumn{2}{|c|}{$\begin{array}{c}\text { Self- } \\
\text { Reporte } 1 \\
\text { Colds }\end{array}$} \\
\hline & & $\%$ & No. & $\%$ & No. & $\%$ & No. & $\%$ & No. \\
\hline 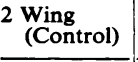 & 595 & 0.84 & 75 & 0.01 & 1 & $0 \cdot 39$ & 35 & $5 \cdot 04$ & 450 \\
\hline $\begin{array}{l}3 \text { Wing } \\
\text { "A"Sqdn } \\
\text { (Control) } \\
\text { "C"S Sqdn } \\
\text { (Trial) }\end{array}$ & 263 & $\begin{array}{l}0.74 \\
0.86\end{array}$ & 34 & 0.06 & - & $\begin{array}{l}1 \cdot 13 \\
0 \cdot 35\end{array}$ & 14 & $\begin{array}{l}7 \cdot 95 \\
9 \cdot 84\end{array}$ & $\begin{array}{l}289 \\
388\end{array}$ \\
\hline Period .. & \multicolumn{9}{|c|}{ GLYCOLLIC ACID } \\
\hline Date $\quad \cdots$ & \multicolumn{9}{|c|}{ JANUARY 12, 1953, TO FEBRUARY 7, 1953} \\
\hline \multirow[t]{2}{*}{ Unit } & \multirow{2}{*}{$\begin{array}{l}\text { Average } \\
\text { Popula- } \\
\text { tion }\end{array}$} & \multicolumn{2}{|c|}{ Colds } & \multicolumn{2}{|c|}{ Influenza } & \multicolumn{2}{|c|}{$\begin{array}{c}\text { Sore } \\
\text { Throat }\end{array}$} & \multicolumn{2}{|c|}{$\begin{array}{c}\text { Self- } \\
\text { Reported } \\
\text { Colds }\end{array}$} \\
\hline & & $\%$ & No. & $\%$ & No. & $\%$ & No. & $\%$ & No. \\
\hline $\begin{array}{l}2 \text { Wing } \\
\text { (Control) }\end{array}$ & 599 & $2 \cdot 54$ & 61 & $4 \cdot 21$ & 101 & $2 \cdot 46$ & 59 & $6 \cdot 67$ & 160 \\
\hline $\begin{array}{l}3 \text { Wing } \\
\text { "A" Sqdn } \\
\text { (Control) } \\
\text { "C"'Sqdn } \\
\text { (Trial) }\end{array}$ & 256 & $1 \cdot 37$ & 14 & $\begin{array}{l}2 \cdot 40 \\
2 \cdot 54\end{array}$ & 26 & $\begin{array}{l}2 \cdot 62 \\
1 \cdot 96\end{array}$ & $\begin{array}{l}25 \\
20\end{array}$ & $\left|\begin{array}{l}13 \cdot 91 \\
19 \cdot 25\end{array}\right|$ & $\begin{array}{l}133 \\
197\end{array}$ \\
\hline Period .. & \multicolumn{9}{|c|}{ POST-GLYCOLLIC ACID } \\
\hline Date & \multirow{2}{*}{\multicolumn{3}{|c|}{\begin{tabular}{c|c} 
FEBRUARY 14, \\
$\begin{array}{l}\text { Average } \\
\text { Popula- }\end{array}$ & Colds
\end{tabular}}} & 1953, & TO 1 & MARC & $\mathrm{CH} 3$ & 1,195 & \\
\hline \multirow[t]{2}{*}{ Unit } & & & & Influe & enza & So & $\begin{array}{l}\text { re } \\
\text { oat }\end{array}$ & $\begin{array}{r}\text { Self } \\
\text { Repor } \\
\text { Col }\end{array}$ & $\begin{array}{l}\text { lf- } \\
\text { orted } \\
\text { lds }\end{array}$ \\
\hline & & $\%$ & No. & $\%$ & No. & $\%$ & No. & $\%$ & No. \\
\hline $2 \underset{\text { Wing }}{\text { (Control) }}$ & 655 & 0.65 & 30 & $0 \cdot 39$ & 18 & $2 \cdot 12$ & 97 & $4 \cdot 78$ & 219 \\
\hline $\begin{array}{l}3 \text { Wing } \\
\text { "A" Sqdn } \\
\text { (Control) } \\
\text { "C"'Sqdn } \\
\text { (Trial) }\end{array}$ & $\begin{array}{l}238 \\
258\end{array}$ & $\begin{array}{l}0.54 \\
0 \cdot 28\end{array}$ & 9 & $0 \cdot 18$ & - & $\begin{array}{l}1 \cdot 32 \\
0 \cdot 44\end{array}$ & 22 & $\begin{array}{l}5 \cdot 10 \\
4 \cdot 43\end{array}$ & $\begin{array}{l}85 \\
80\end{array}$ \\
\hline
\end{tabular}

With the common cold the position is perhaps a little more doubtful. Initially all three groups were very similar with rates of $0.84,0.74$ and 0.86 per cent. During the issue of impregnated handkerchiefs the rate in "C" Squadron was significantly lower than that of " $A$ " Squadron and No. 2 Wing. In the "post-glycollic period" its rate remained lower though not to a significant degree. On the Other hand the incidence of self-reported colds was not very different between squadrons " $A$ " and " $C$ " except during the period of issue of handkerchiefs when it was higher in those with the treated handkerchiefs. The total incidence of "colds" in these two squadrons was therefore 8.7 and 10.7 per cent. in 
the "pre-glycollic period", 17.5 and 20.6 per cent. in the "glycollic period", and 5.6 and $4 \cdot 7$ per cent. in the "post-glycollic period". There is clearly nothing very striking here, though the lower incidence of colds observed on sick parade may indicate a value in the impregnation by glycollic acid. A longer trial would be needed to substantiate it.

\section{SUMmARY}

(1) Field studies of possible methods of reducing the spread of upper respiratory diseases were carried out at an R.A.F. training station, the population and general setting of which were peculiarly suitable for strictly controlled trials.

(2) The impregnation of handkerchiefs with octyl cresol produced no lower incidence of upper respiratory disease in those using them compared with the incidence in those using untreated handkerchiefs.

(3) A trial combining sterilization of barrack room air by ultra-violet light, reduction of airborne bacteria by oiling floors and textiles, introduction of screens between beds, and the use of handkerchiefs impregnated with octyl cresol failed in this population to reduce the incidence of upper respiratory diseases.
(4) The same general measures together with the impregnation of handkerchiefs with glycollic acid produced no difference in the incidence of influenza and sore throats, but gave a somewhat lower incidence of the common cold. This calls for further trials.

Our thanks are due to the Air Officer Commandingin-Chief, Technical Training Command, and to the Commandant and Officers of the R.A.F. station concerned for permission to use the station, and for much cooperation. From the Air Hygiene Committee of the Medical Research Council and the laboratory staff of the Central Public Health Laboratory at Colindale we have had much help and advice.

The Civil Consultant in Medical Statistics to the Royal Air Force, Professor A. Bradford Hill, C.B.E., F.R.S., has been most kind in critically reviewing this paper; and without the authority and guidance of the DirectorGeneral of Medical Services of the R.A.F. the trials would have been impossible.

\section{REFERENCES}

Bourdillon, R. B., Lidwell, O. M., and Lovelock, J. E. (1948). Med. Res. Coun. spec. Rep. Ser., No. 262 , p. 59.

Dumbell, K. R., and Lovelock, J. E. (1949). Ibid., 1, 777. , and Lowbury, E. J. (1948). Ibid., 2, 183.

Harwood, F. C., Powney, J., and Edwards, C. W. (1944). Brit. med. $J ., 1,615$.

Morant, G. M. (1949). "Surveys of the Heights and Weights of Royal Air Force Personnel", Flying Personnel Research Committee Report No. 711. 